\title{
Second homes during corona - safe or unsafe haven and for whom? Reflections from researchers around the world
}

Kati Pitkänen, Finnish Environment Institute

Olga Hannonen, University of Eastern Finland

Stefania Toso, University of Milan Bicocca

Nick Gallent, University College London

Iqbal Hamiduddin, University College London

Greg Halseth, University of British Columbia

C. Michael Hall, University of Canterbury

Dieter K. Müller, Umeå University

Andrey Treivish, Institute of Geography, Russian Academy of Sciences

Tatiana Nefedova, Institute of Geography, Russian Academy of Sciences

The COVID-19 pandemic has rapidly slowed down, reduced, and changed the flows of tourism mobilities. While many national borders have been closed and/or regulated, the main emphasis has been on domestic travelling and tourism.

Second homes are a major form of domestic tourism in many countries, especially the Nordic countries, Southern Europe, Russia, North America, Australia, and New Zealand where a significant proportion of people have access to a second home, often located in rural areas. Soon after the outbreak of the pandemic and the closure of schools, offices, shops, and restaurants, people started to flee to their second homes in search for a safer and more meaningful place for isolation. The city dwellers' rural exodus, and the role of second homes during the pandemic, appeared on the public agenda in many countries. The purpose of second homes as a place for recreation quickly changed into serving the function of pandemic shelters.

Whereas the cottage, mökki, stuga, or dacha usually attract public attention on the pages of lifestyle magazines or idyllic summery reports of country living, this time second homes suddenly appeared in the official statements of governments and ministers, and on the front pages of newspapers. Recommendations to visit, or not to visit, second homes were set against questions about the health risk second homes may pose and who has the right to be in rural areas. 
Initial studies on the impact of COVID-19 on tourism and in particular on second homes have been rapidly emerging, emphasising the relevance of the issue in different empirical contexts (e.g. Baum \& Hai, 2020). The rush of an urban population to second homes in Russia, Turkey, the UK, and France has stressed the importance of second homes as places with lower risks of infection and locations for self-isolation (Gallent, 2020; Grigoryev, 2020; Nikolaeva \& Rusanov, 2020; Seraphin \& Dosquet, 2020; Zogal et al., 2020). A possibility to relocate to a second home during the pandemic has been regarded as a "privileged escape" (Zogal et al., 2020). This second home migration, in turn, has met resentment from the locals (Gallent, 2020; Nikolaeva \& Rusanov, 2020). While second homes have provided a safer space for urban residents during the pandemic, the exodus of city dwellers to their second homes has drastically increased the environmental burden on those rural locations in Russia (Bobylev, 2020). In the US and Italy, the geographical spread of the COVID-19 has been linked to social ties, which include among others second home visits. In the US context, the spread of the pandemic followed the pattern of second home mobilites; a similar pattern has also been noted in Russia (Kuchler et al., 2020; Nikolaeva \& Rusanov, 2020).

We invited second home researchers throughout the world to converse on second homes during the first wave of the pandemic. Their thoughts are collected in this conversation paper country by country. We start our tour in Italy, the first European country hit by the virus and by mobility restrictions. We then move to the UK, where the pandemic has resurfaced debates about second homes and housing inequality. The tour continues to Canada, where people have escaped and expanded their personal and family safety bubbles to their cottages. In Australia and New Zealand, many communities and destinations have had to balance the health and economic risks induced by second homes. The Nordic countries have witnessed heated debates about the health care capacity of rural communities and the health risks associated with second home tourism from the capital regions. The long traditions of freedom of movement between the Nordic countries have also been challenged by the reinstalling of border controls and mobility restrictions; which have had an effect also on cross-border second home ownership and tourism. Our tour ends in Russia, where the dacha's role as a place of escape and poems is being reinforced during the pandemic.

Our tour reveals that although second home cultures and contexts are different, people all over the world have looked for 'escape' and safety at their second homes during the pandemic. To be seen as a sanctuary is not a new role for second homes, as the rich urban elites have always fled to their country estates for safety during times of upheavals and pandemics such as the Black Death in the Middle Ages or Spanish Flu in 1918-1919. Much like before, such an escape has not been without resistance from the rural dwellers. The idea of second homes as 'sanctuary' has been contrasted with fears of urban dwellers spreading the virus to rural areas and exceeding the limits of the local health care capacity. The selected countries implemented different, and sometimes contrasting policies to lowering the pandemic spread, ranging from a total lockdown in Italy to a more relaxed approach in Sweden. Despite these differences, second home tourism policies in many countries have followed quite similar official mobility restrictions or at least recommendations to stay away. After these restrictions were lifted, second home sales and rent- 
als peaked to all-time highs. The individual articles cover country-specific political decisions, public debates, and strategies about second homes, revealing case-specific historical and social issues, such as abandoned villages in Italy and housing crisis in the UK among others.

It is too early to tell what the post-COVID-19 future holds for second homes. There are some evaluations that the desire for privacy and seclusion would favour private accommodation, such as second homes, over other traditional tourist accommodation, such as hotels. The growing interest in second homes is estimated to be supported with semi-mobile second homes, and other forms of mobile shelters (Zogal et al., 2020). Indeed, sales and rentals all over the world are peaking as people are investing in a safe place, but is the peak temporary or does it signal a 'new normal' in leisure mobilities in favor of domestic short-haul and close-to-nature destinations? How will the global economic uncertainty impact people's possibilities for investing in their own safe haven? How will the changing perception, and even hostile sentiments over non-local second home owners, affect the popularity of second homes? How much pressure will second home populations put on rural services and infrastructure? Can local communities sustain these pressures and how should the burdens and benefits of the multi-locals be shared between the different places of residence? Besides second homes, everyday mobility practices have also been under turmoil with the home becoming the place for both (remote) work and leisure. Whether the rapid digitalisation and adoption of 'place independent' work and education plays in favour of the first or the second home, or multi-local lifestyles, remains to be seen. These are some of the questions proposed by our commentators. In contrast to many other forms of tourism, second homes are permanent nodes of mobility during people's life courses where they return year after year, sometimes even from one generation to the other. If nothing else, it is clear that second homes will be on the post-COVID-19 tourism research agenda for years to come.

\section{Going back to the borghi in Italy?}

Italy was the first European Country to be hit by COVID-19 and thus also the first one to deal with its impacts on the economy, behaviour patterns and the daily hygienic norms to be adopted to prevent the spreading of the virus. What became rapidly clear to citizens living in urban areas was that, despite having a better access to community services and sanitary infrastructures, their social relationships and lifestyle would have been deeply affected by mobility restrictions. Indeed, in Italy a multitude of urban dwellers are also second home users, whether the holiday house is a property of theirs or a rented one. Despite the huge gap in the scientific knowledge about the "tourism that doesn't appear" due to inappropriate analytical tools and missing reliable data (Romita, 2010; Volo, 2018), the pandemic outbreak has proven the evidence of its consistency, since the topic of second homes has been a constant trend in the public discussion and a recurring object in regulations.

As the first measures came into action in the last week of February imposing the closure of schools in Northern Italy, secondary and holidays houses typically located in the rural areas or in isolated small villages became very rapidly seen as ideal and safe shelters where to self-isolate with the whole family while teleworking, being less exposed to crowded spaces and police 
regular checks. From the 9 th of March to the 3 rd of June, unprecedented strict restrictions were imposed to individual mobility as an extreme emergency measure: with the decree \#Iorestoacasa (\#Imstayinghome) a nationwide lockdown prevented anyone from stepping out of their first residence address except for work, health or emergency reasons. Access to second homes was explicitly forbidden for almost three months both by national and local decrees, but some time was (intentionally?) left by the Italian government for second home owners to move before the implementation of the ban. The exodus (D'Alessandro, 2020) from the North to the South and from the city to the countryside, mountains or seaside that occurred proves the high level of mobility that characterises spatial and social practices within Italian families.

The issue was widely discussed on social networks and daily newspapers: the ban on reaching secondary houses, paying property taxes in the meantime, was considered unconstitutional by many, and concerns about the lack of regular maintenance were raised. In some settings, a tension developed between locals and extra-locals (i.e. second home owners). On the one hand, in areas with the highest concentration of second homes the local community was waiting for the summer season to begin: giving the substantial decrease of international flows, the economic support of second home owners was crucial. On the other hand, a shared fear towards citizens seen as possible vehicles of the virus generated negative feelings towards second home owners, leading in some cases to spontaneous reports by the local population to the police (Larizza, 2020). This is the case of urban dwellers moving from Milan to popular seaside destinations in the South, where they still have inherited family properties and where they usually spend their vacations fuelling a peculiar form of residential tourism, the so-called "residential root tourism" (Perri, 2016). The same attitude was detected in small islands with a tourist vocation, like Capraia, where the owners of second homes were explicitly told not to go, and among small communities located in the mountain areas, who expressed their willingness to forbid extra locals entering the valleys, urging strict monitoring of accesses, with the slogan "staying at home is also good for the mountains" coined by the National Union of Municipalities and Mountain Communities (UNCEM, 2020).

As travel agencies have foreseen, Italy is now facing a step backwards to tourism behaviours similar to those of the post-bellum time, a domestic tourism based on second homes and short trips. The pandemic has done nothing but making even more evident in a few months a process that has been underway for decades, a renewed awareness of the restorative value of nature and environment (dell'Agnese, 2018), bringing a multitude of citizens to approach naturalistic tourism and ecotourism. It shows a sort of revenge of the slow places, those less blazoned and more remote, therefore more suitable for detox from forced confinement, that in some cases gained the "COVID-free" label. During the pandemic the debate has been enriched by the Italian stararchitects Stefano Boeri and Massimiliano Fuksas: according to them, going back to the borghi (small rural villages) should be framed into a national strategy, as they are fundamental territorial units that have proved to better respond to global challenges such as the pandemic and climate change, in terms of social ties robustness and actions for resilience. The same places are now invaded by millions of tourists attracted by temporary living in the inner areas of the country, putting a fragile ecosystem at risk. 
However, it must be highlighted that those second home owners who managed to move to rural areas before the restrictions imposed by the ministerial decrees became effective significantly contributed to the survival of small rural shops and businesses, providing a sensible recovery for the fragile economy of marginal areas. The isolation factor leading rural villages towards abandonment or depopulation could prove to be the trump card for many small towns, which are dealing with growing commercial desertification and the lack of services, from healthcare to education and welfare infrastructures. Nevertheless, politicians and citizens hope that a renewed interest in second homes will help recover that excess of the housing stock (Curci \& Zanfi, 2018), laying abandoned in marginal areas. Initiatives such as "1 euro houses" (Marchetti, 2020) or free rental of empty holiday apartments had a boost during the pandemic. Small businesses that boomed during the pandemic outbreak such as home delivery of local agricultural products, services to help manage empty properties, but also online school classes, could help increase the use of second homes for longer periods, facilitated by teleworking, in a logic of multilocal living.

Although it is difficult to predict how the final goal of revitalizing almost ghost villages will be accomplished (The Local, 2020), the most desirable result is that new situated strategies will be developed to recycle the huge abandoned or under-utilised building stock owned by the middle class (Lanzani \& Zanfi, 2017), possibly including second home owners as relevant stakeholders.

\section{The UK is a country of "haves" and "have nots": notes on the rural exodus}

Twenty years ago, the writer and political commentator George Monbiot argued that "there is no greater inequality in this country than that some people should have two homes while others have none" (Monbiot, 1999). Second home buyers in Britain were said to be engaged in a "cannibal feast", preying on "the lives of the poor". The general debate on second homes across all parts of the UK has been shaped by the reality of a national housing crisis, which has seen house prices soar, affordability plummet, and the concentration of housing wealth in the hands of baby boomers (Gallent, 2019). The problem is no longer "people having two homes" but the phenomenon of multiple property ownership for a fortunate few alongside rising rents and poor housing for the many. These issues have been brought into sharp relief by the COVID-19 pandemic.

On the one hand, we had the spectacle of wealthier Londoners heading into the country - seeking the relative safety of isolation. And on the other, there were widespread reports of the psychological costs of spending months in lockdown in cramped flats that have no external space (Judge \& Rahman, 2020). The pandemic served as a reminder that the UK is a country of haves and have nots: gross wealth and income inequalities are expressed in the housing resources available to different families. Many of those heading to second homes will already have comfortable lifestyles in London, and having a home in the country is just an added bonus.

The exodus, however, drew sharp criticism. Popular second home hotspots saw an influx of out-of-season seasonal residents. In the South East of England, the East Anglian Times reported the arrival, en masse, of Londoners to the Sussex Coast, stripping the shelves of local shops 
and "increasing the risk" of infection to the elderly populations of many villages. A very similar challenge was faced in Cumbria where authorities issued a plea for these out-of-season holiday-makers, many from the urban north-west, to go home. In Wales, there were immediate calls to ban people from travelling to second homes and "tourists go home" signs became commonplace, erected by anxious and angry locals (see Gallent, 2020).

The flight to second homes was viewed as a health risk. Urban areas are better endowed with hospitals and general health care. Rural areas are home to an older population and health services are less developed. COVID-19 infection had been brought to the UK from overseas, striking key transport hubs - the big cities with international links - first. Containing infection was the overriding priority, and this meant avoiding the "counter-urbanisation" of COVID to rural communities in the cars of second home owners. So the message was a simple one: stay put and do not visit second homes.

That message was issued by the UK Prime Minister in late March: stay at home and do not stay overnight anywhere other than your primary residence. The official message, however, was undermined in different parts of the UK by some politicians, scientific leaders and political advisors failing to take note of their own instructions. There had been great anger at the March exodus to second homes, but that faded as more people stayed away from rural communities, and was thereafter refocused on the hypocrisy and inconsistency of government's core messages.

There is of course a longstanding second home debate internationally: whether they are a curse or a blessing for rural communities (Coppock, 1977), bringing benefits that outweigh costs or vice versa. Whatever the balance was before COVID-19, it changed during the crisis: decamping to second homes in areas under-supplied with hospitals or other medical services came to be seen as a selfish act, prioritising private over public interest.

Amongst the possible futures for second homes in the UK, two stand out. First, recent experiences of bad housing in cities - and otherwise good housing lacking private external space - may drive different housing choices. Although there may never be a return to the situation faced during the last few months, the perception of the more limited utility of smaller urban homes may have a lasting effect, shaping market choices, including the decision by wealthier households, who want to avoid being caught out by the return of similar crises in the future, to purchase second homes. Those households will no doubt have seen the negative reactions against second homes in some communities but may nevertheless be attracted to locations with concentrations of seasonal visitors - safety in numbers. Seeking sanctuary at times of crisis is a natural human impulse, and purchasing a second home now will make that possible in the future.

But second, anti-second home sentiment seems to have reached a new high water mark. Recent reporting in the Financial Times (2020) reflected on the arson campaign against the homes of seasonal residents in Wales from 1979 onwards. At that time, hatred of second homes was harboured by a nationalist minority. But today, in the aftermath of the lockdown (and with the presentation of second home owners as selfish "super spreaders" in rural communities) that sentiment seems to have broadened. If prospective owners expect to feel neither welcome nor safe in hostile rural communities, then other housing market choices might be made: bigger 
suburban homes rather that rural boltholes. Housing inequalities, however, will remain - being expressed in these new choices and in continuing hardships for the poorest households. The pandemic has brought these inequalities into sharper relief, but only through a new housing politics - one that prioritises good housing for everyone over the freedom of a few to conspicuously consume - will it be possible to end the "cannibal feast".

\section{Canada's cottage country and wilderness "isolation bubbles"}

Second homes occupy important places in the Canadian psyche and on the Canadian landscape. They are places of solitude, places of family; they are places of quiet, places of community; places of rest, places of recreation. Most importantly, perhaps, they are places of "escape" from our day-to-day cares.

As Winter turned to Spring, then Summer, and now Fall, in the year of COVID-19, there continue to be worries and concerns about how the pandemic is impacting second home and recreational lifestyles as well as the small-town economies of Canada's cottage country. The debates are familiar to other second home regions - urban residents are seeking respite from lockdowns and solace in their rural retreats - rural governments are hoping second home owners can reinvigorate pandemic-injured rural economics, even while some rural residents and business owners worry about the spread effects of "newcomers" streaming into their region. As reported COVID-19 cases rose and fell over the months, these concerns, and the debates they support, also rose and fell.

"Going to" the second home this year has evolved along with our responses to the pandemic. The month of May was particularly challenging in Canada - as the 3-day "May long weekend" traditionally signals the start of summer activities and the first time many people will go to their lakeside, oceanside, wilderness, or mountain second home. This year, May was also pivotal in second home debate. At the beginning of the month, news coverage highlighted health regulations about avoiding all nonessential travel (Carter, 2020). There were regulations, enforced by fines, preventing people from crossing provincial borders. By the end of the month, however, people were expanding their personal or family "bubbles". As Spring gave way to Summer, the media coverage also began to shift towards messages about intra-regional and intra-provincial travel as various economic "restart" plans looked to "domestic" tourism as a stimulus tool (Missick, 2020). Emerging from quarantine, many recognized that "Cottage living is 'something that people are really, really longing for'...' (Cotnam, 2020).

Through the Summer and Fall, the pressure to open second homes as "wilderness isolation bubbles" increased (King, 2020). The relaxing of some inter-provincial travel bans helped, though the Canada / US nonessential travel border closure remained in place. In Ontario, which has more second home properties than any other province, a provincial emergency order had originally prohibited short-term rentals of private second homes until at least June 30. Under public pressure from owners and users of second homes, and from rural businesses and governments concerned about both health and economic wellness, this order was lifted on June 5 . Canada's "cottage country" was opened up ... as long as health protocols were followed. 
As reported in news coverage, demand for camping, recreational vehicle use, and second home rentals was increasing because many typical summer pursuits, including overseas vacations and children's summer camps, were not happening (Bell, 2020). News coverage from numbers of provinces noted that second home rental demand was higher than most operators had ever seen, and that bookings were filling capacity over the Summer and into the Fall (Klowak, 2020). As restrictions began to ease, and the weather turned warmer, there was an increased desire to swap "staying isolated at home" for staying at "isolated second home retreats" away from the stresses of the modern ... urban ... now pandemic ... world.

Within discussions about the implications of the pandemic for our previously mobile world and mobile lifestyles, numbers of issues are already "in the mix" in Canada. For example, as our vacation and recreational mobility horizon has narrowed, questions have been raised about the duration of those constraints and their impacts on a future re-orientation of people's travel/ recreational investments and time. Will second home ownership trend toward more "domestic" ownership? Can second home tourism replace the economic contributions to rural economies of international tourists? Will the demand for second home ownership lead to a market-driven increase in prices which negatively impacts rural housing affordability?

Within the emergent commentary on an "urban exodus" by people seeking more space in a less dense rural or small town setting, several elements may receive further impetus from the pressures of the pandemic. The first concerns the changing demographic trajectory of rural places and regions - as it would take only a small share of urban residents to shift their housing preference to put tremendous pressure on rural housing markets. To this we can add already important property conversion pressures on second homes. These include moves by those whose socio-economic means will allow them to retire to live full-time at their second home property, as well as those whose working life will allow them to relocate and work from their second home property. All of these issues were already at play in rural Canada; the question is how will the pandemic impact these new challenges and opportunities.

\section{Second homes in New Zealand and Australia: delicate balance between personal and economic health}

Second homes have been a point of controversy in both Australia and New Zealand since the outbreak of the pandemic and the first "lockdowns" were put in place. In order to restrict mobility and the spread of the virus, governments in both countries requested people not to travel to their holiday homes. Nevertheless, there has been substantial tension between the desire of many people who have their main place of residence in large urban centres to leave the city and head to their second home because they see them to be safer for isolation, while rural areas have been trying to deter second home and mobile home owners, including marine craft, because of fears of the virus, a generally older population, and the lack of medical facilities if there are local infections (Hall et al., 2020; Radio New Zealand, 2020). For example, in the case of the small town of Walpole in south-west Western Australia, which has a very large number of holiday homes but a permanent population of only 500 people, the local supermarket barred non-residents from en- 
tering to shop (Mochan, 2020). In parts of rural Australia and New Zealand restrictions were also put in place to protect Indigenous communities (ABC Kimberley, 2020). Yet the implementation of measures on non-permanent residents in many communities along with government restrictions on mobility have also led to problems for mobile second home owners (Hall \& Müller, 2018), many of who are referred to as "grey nomads", because they have found it difficult at times to get access to appropriate places where they can park their vehicles as well as purchase supplies.

In Australia, the tensions between second home owners and local communities were well established by late March, 2020. However, in Australia housing taxation policies means that many second homes are also treated as investments and are rented out as short-term holiday accommodation to pay for mortgages. This has therefore meant some owners have come under increased financial pressure because of the drop in tourist traffic creating financial issues for some owners as well as the economic contribution of second homes to regional economies (Hayes \& Loney, 2020). Nevertheless, in the longer term, the COVID-19 pandemic is perceived to be good for second home investment and people not only perceive rural areas as safer and healthier than urban centres but also because there is a belief that they would be able to work online (Ross, 2020). However, the potential for this to actually happen is rather uncertain given that many rural areas in Australia and New Zealand have relatively poor Internet access (Payne et al., 2019). Similarly, COVID-19 has led to an increase in sales of caravans and mobile homes given that it is not possible to take overseas holidays and, in some cases, even domestic holidays to some destinations because of COVID-19. In late June 2020 the Caravan Industry Association of Australia reported that since the easing of mobility restrictions, every state and territory had experienced a "boom" in caravan sales and enquiries, some by up to 30 per cent (Cassidy, 2020).

The tension between the permanent residents of communities in rural regions with substantial numbers of second homes and second home users as a result of COVID-19 is likely to continue for the foreseeable future with many aspects yet to play out. The negative response to many second home owners, some of whom have owned properties for decades, revisits issues of what does being a permanent resident actually mean both from the perspective of government decisions and the actions of some local businesses. Measures to restrict mobility also often failed to take account of the large number of people who own caravans and motor homes. Both second homes and caravanning are integral to the tourism economies of many rural areas in Australia and New Zealand (Fieger et al., 2020), even more so given the promotion of domestic tourism, yet in some places such visitors are not welcome because of the perceived health risks they bring. In the case of Kangaroo Island in South Australia tourism represents an A $\$ 147 \mathrm{~m}$ business with only 1,815 (57\%) of the 3,150 houses on the island being permanently occupied, the rest being second homes or rental accommodation. However, as Jon Lark, owner of a cellar-door distillery on the island stated, "We had to go into lockdown... The medical service here has one ventilator and one ICU. If COVID hit us, we were fucked" (quoted in Kurmelovs, 2020). The concerns regarding second home visitors is therefore strong in many communities but the delicate balance between personal and economic health for such locations is causing considerable stress, with second homes being a focal point of anxiety. Whether this may permanently change the perceptions of some locations as welcoming to second home tourism remains to be seen. 


\section{Re-evaluating rural healthcare capacities and second home access in Sweden}

Even in Sweden, the COVID-19 pandemic caused considerable debate. However, as Back (2020) recently revealed, many local jurisdictions lack knowledge of the number and use patterns of second homes. Departing from the notion it can be concluded that much of the ongoing debate has been based on occasional observations and more or less qualified guesses. However, this overview is based on newspaper articles featuring national news, their regional adaptations and numerous comments. The high number of items - more than 90 in the first half of the year - indicates the pertinence of the topic and though articles originate from the entire country, it is obvious that second home resorts along the southern coastlines reacted most intensely in relation to the anticipated COVID-19 consequences. In this context, these places positioned themselves as the opposite to the capital region of Stockholm, which in the Swedish context has been seen as the epicenter of the pandemic.

In the Swedish debate two separate issues can be discerned. In the first phase of the pandemic a focus was on the impact of the disease on second home communities. Many households chose to relocate early to their second homes in order to avoid crowding in cities. According to Swedish law, second home owners have the right to receive the same social support - often help in the home - in their second home destination as in the municipality where they are registered. Several municipalities with high numbers of second homes saw a challenge to provide these services during the pandemic because of increased sick leave among their staff already in March. An additional demand was therefore beyond the available capacity, they argued. However, the argumentation was not totally unison. Instead, some voices stated simultaneously that second home owners should be stopped because they were spreading the disease from Stockholm to other parts of the country. This debate peaked before the Easter weekend and revived when the summer vacations came close.

Since the same politicians voiced both arguments, the question remains whether the capacity argument was just a more technical justification for stopping the second home owners while the true reason was fear.

However, the municipalities forwarded a formal claim to the government asking for a change of law. While the social democratic government was somewhat reluctant towards the claim of changing or at least pausing the law, the bourgeois opposition was quick in supporting the protesting municipalities. However, the jurisdiction finally rejected the claims; the law cannot simply be changed without a thorough assessment process, which was not possible because of the short notice.

At the same time newspapers reported from other municipalities that the issue of social support was marginal since only few second home owners in fact requested those services, and hence, these municipalities did not support the initiative to ban second home owners. According to a survey, about $70 \%$ of the municipalities who answered did not aim for any restrictions (Uppsala Nya Tidning, 2020). 
The issue of health care provision - in Sweden, a responsibility for regional authorities was not particularly discussed in relation to second homes. Considering that most second home owners have the properties within $50 \mathrm{~km}$ from their primary home, the issue of interregional second home ownership and thus cross-border health care provision is a minor issue only. Furthermore, a governmental recommendation to stay within the home regions, valid until midJune, contributed to limit the health care challenge.

The other dimension of the COVID-19 pandemic on second home tourism entered the news in April and accelerated during June. Despite the immediate impact of the pandemic on employment and economy, real-estate agencies noted a dramatic increase in second home demand resulting in increasing prices. This development contrasts urban property market development that noted stagnating and indeed decreasing price levels for apartments and houses. Since many households were unsure whether they would be allowed to travel during summer, it was argued, they looked for alternatives nearby, which entailed a greater interest for second homes, for RVs, and caravans. However, there was also concern about the long-term consequences of economic decline causing shrinking demand in the aftermath of the pandemic. Similarly the pandemic was also seized as an opportunity to commodify second homes by renting them out to other households who were "stranded" for a summer in Sweden.

In some areas the absence of Norwegian and Danish cross-border shopping tourism was discussed. This debate comprised second home owners, too, who after returning to Norway needed to be in quarantine for two weeks. Still, it seemed that several Norwegian households would still use their second homes during summer. To what extent this happened is however too early to say.

Few commentators raised other issues. Worth noting are articles in Arbetet (2020) pointing at the fact that second home ownership in the first place is not self-evident for all but still a marker of class and income and in Smålänningen (2020) where the consequences of temporal living in substandard housing on lake water quality was highlighted. Finally, reviewing their spring experiences, during summer several commentators started to speculate about the future of home offices and the pandemic's long term impacts on the organization of work.

\section{When is the right time to go to the mökki? Mixed responses to second home mobility in Finland}

"Now is not the right time to travel to the mökki" emphasised Sanna Marin, the Finnish Prime Minister in the Government press conference on 25th March (Yle, 2020a). Just before she had announced heavy travel restrictions between the capital region of Uusimaa and the rest of the country (Finnish Government, 2020). One of the main reasons for the restrictions was to prevent people's leisure mobility from the capital region (with the highest number of infected persons) to other areas with less health care capacity and fewer infections.

In Finland, people have relatively flexible rights to use the municipal health care regardless of the location of their permanent residence. This puts pressure on the health care capacity in regions with high seasonal variations in population (Parhiala et al., 2020) and the additional 
pressure during the pandemic was not welcomed by officials. According to Parhiala et al. (2019), in the popular second home regions over $20 \%$ of emergency medical visits during the normal summer months are made by people living permanently elsewhere.

In the official government discourse, second homes were seen as non-essential mobility that should be restricted until the pandemic outbreak eased. But, contesting views were also presented. Scholars of constitution and human rights law publicly accused the Government for "playing God" (Scheinin \& Rautiainen, 2020). They argued that the closure of Uusimaa was against human rights as it prevented the citizens from seeking protection against the virus by escaping to their second homes. Many second home owners also felt that moving to the second home would enable them to better avoid human contacts while simultaneously supporting an active lifestyle that would not otherwise be possible in densely populated urban areas.

Travel to second homes during the pandemic has been closely monitored by the mainstream media. Using mobile phone data, the media reported, for example, that during the days before the closure there were 70 per cent fewer people in the Helsinki railway station and 40 percent more in some of the biggest second home municipalities compared to more normal time periods (MTV, 2020). Although most people quickly returned to their urban homes after the Government recommendations, some people decided to stay at their second homes. This raised fears among the locals, and in some municipalities there were heated debates fuelled by local politicians. In one of the most popular second home regions, municipal leaders published a joint statement that second home owners are part of the local community and people should 'cool down' and 'avoid accusations' (Länsi-Savo, 2020).

The Uusimaa closure ended after three weeks (on the 15th of April) and other domestic travel restrictions have gradually been lifted. The perception of second homes as a safe haven, together with limited possibilities for travelling outside Finland, have encouraged many people to plan a second home holiday. A day before the midsummer, a national holiday traditionally celebrated at rural second homes, the Prime Minister tweeted: "Now is the right time to travel to mökki". In the summer, second home sales peaked, rental cottages were fully booked, and roads were filled with caravans and RVs (Savon Sanomat, 2020; Yle, 2020b). Finns stayed almost 50\% more nights at their own or rental cottages (Statistics Finland, 2020) and purchased $40 \%$ more second homes (Yle, 2020c) in the summer 2020 than the year before. Many who stayed at their second homes or rented a cottage have moved the home office into the countryside as the summer has changed into autumn and Finland has been hit with the second wave of the pandemic. The popularity of second homes in Finland combined with remote work advice and/or requirement has developed a new type of domestic tourism - etätyömatkailu or remote work travel (Rantala, 2020).

While Finns were enjoying their second home vacation to the full this summer, some foreign second home owners were less fortunate. Currently, foreign second home owners from the EU and EEA are allowed to visit their second homes and other properties in Finland (Rajavartiolaitos, 2020a). Norwegian, German, and Swedish second home owners have added to the great Finnish mökki summer of 2020 . However, border regulations have been changing every other month, raising uncertainty among foreign property owners. Russian nationals, who are the biggest group of foreign second home owners in Finland, could not cross the border to visit 
their properties due to the border closure since March 19 (Rajavartiolaitos, 2020a, b). Concerns and frustrations being shared, among others, in Russian second home owners' Facebook groups include suspensions of the border-crossing into Finland and the processing of visas. Only in October 2020 did Finland again allow Russian property owners to visit their Finnish second home properties. This permission, however, was not enacted on the Russian side, making property visits for many a game of chance (Jeskanen, 2020). Thus, the outbreak of the COVID-19 demonstrated that second home tourism in Finland is depended on the course of the pandemic.

\section{Russia}

Russians in general have been restricted from foreign travel this summer. Thus, the use of domestic second homes has significantly increased. It has been estimated that all second home or dacha owners are using their rural properties this summer, and the rental enquiries have increased by several times in comparison to the previous year (Nikolaeva \& Rusanov, 2020). The demand for second home mobility in Russia is high, and seems to extend across international borders.

\section{The Song of Dacha}

Should you ask me, whence these stories?

Whence these legends and traditions,

With the odors of the forest,

With the dew and damp of meadows,

With the curling chimney smoke?

I should answer, I should tell you,

"From my dacha, my great treasure".

should you ask me, what is dacha?

I should answer and explain.

Called in English summer cottage,

Same as German Sommerhaus,

Same as Finnish kesämökki,

Swedish fritidshus or stuga,

And la casa di campagna,

And so on, and so forth.

Second home in a nutshell.

Why do Russians love their dachas?

This is due to their climate,

With its long and harsh winter,

With its short and valued summer.

This is also due to their

Urban small and cramped apartments

After which they want some wild

Space, and wind, and sun, and water, 
Fresh green herbs and lavish gardens, Hidden by blind fence. No matter.

Furthermore, this is because

Of the history of dacha

From the noblemen's lifestyle

Through the wars and starvations

When the land could save and feed.

Where a dacha can be found?

Anywhere in the country

Outside its giant cities.

Need not be pretty far,

At the edge of many towns

Or, sometimes, inside the latter,

As well as in deeper areas

Where the taiga's all around,

And a bazzard hovers over

An abandoned barren field.

It can also be located

At a tender resort seaside,

But it would be more expensive.

Who and what are Russian dachniks?

They have different backgrounds,

From the poorest to the richest,

Millions living in their hovels

And the few who built a palace.

Often grandmas with their grandsons

Or young parents with their children,

Both lone single persons

And extended, larger families.

More than half of the townspeople

Own a sort of Russian dacha.

What is dacha for those Russians?

First, a place to rest or work,

It depends on what you need.

You may take a telework,

Or find a hobby there,

Writing poetry, for instance.

Second, this is a location

For your countless investing

Up to every taste and budget.

Third, your subsistence farming 
Brings a lot of pleasant fruits,

Even though they contain

Oil products, heavy metals,

Other POPs, hazards and toxins.

Still you call them green-organic.

Forthly, you forget the city -

Dusty, noisy, tense and sleepless.

Cities in early 2020

Were really fraught with peril.

How is coronavirus

Linked to Russia's dacha practice?

When the wave of infodemic

Covered our mega-centers,

Many rushed in search of refuge

To their near and distant dachas.

No one would say them "no"

In the scared city proper,

Which was happy to get rid of

Some potential sick patients.

Yet, the hosting populations

And the municipal bodies

Did not welcome risks and dangers

From the mass of virus carriers

Calling for their isolation

During just a couple of weeks.

An unusual diffusion

In the first COVID months

And the market reaction

With increasing dacha prices

Here's what the results were.

Well, excuse me, my dear reader,

For my digression rough and far

From the language of Longfellow.

However, if you ask me

Something else about dachas,

I will answer, I shall tell you... 


\section{References}

ABC Kimberley (2020, March 19). 'Stay home': Kimberley coronavirus tension prompts call to restrict 'unsafe' tourists. ABC News. https:/www.abc.net.au/news/2020-03-19/coronavirus-call-to-protect-aboriginal-communities-from-tourists/12066254

Arbetet (2020, May 20). America Vera-Zavala: Helgens resa till sommarhuset är inställd, men för vem? Arbetet. https://arbetet.se/2020/05/20/helgens-resa-till-sommarhuset-ar-installd-menfor-vem/

Back, A. (2020). Temporary resident evil? Managing diverse impacts of second-home tourism. Current Issues in Tourism, 23(11), 1328-1342. https://doi.org/10.1080/13683500.2019.1622656

Baum, T., \& Hai, N. T. T. (2020). Hospitality, tourism, human rights and the impact of COVID-19. International Journal of Contemporary Hospitality Management, 32(7), 2397-2407. https://doi. org/10.1108/IJCHM-03-2020-0242

Bell, J. (2020, May 26). Despite hiccup, record reservations for B.C. campgrounds. Times Colonist. https://www.timescolonist.com/news/local/despite-hiccup-record-reservations-for-b-c-campgrounds-1.24141744

Bobylev, S. N. (2020). Environmental consequences of COVID-19 on the global and Russian economics. Population and Economics, 4(2), 43-48. https://doi.org/10.3897/popecon.4.e53279

Cassidy, T. (2020, June 28). Caravan sales boom during travel ban as young Aussies and families move in on 'grey-nomad holiday'. ABC News. https://www.abc.net.au/news/2020-06-28/border-closures-see-caravan-sales-surge-across-australia/12400134

Carter, A. (2020, May 08). Ontario Premier Doug Ford briefly visited cottage after asking residents not to. CBC News. https://www.cbc.ca/news/canada/toronto/ford-cottage-covid-19-coronavirus-1.5561167

Coppock, J. T. (Ed.) (1977). Second homes: Curse or blessing? Pergamon.

Cotnam, H. (2020, May 13). Cottage country dilemma: To go or not to go. CBC News. https://www. cbc.ca/news/canada/ottawa/covid-19-cottage-dilemma-non-essential-travel-versus-essential-to-well-being-1.5564710

Curci, F., \& Zanfi, F. (2018). Il costruito, tra abbandoni e riusi. In De Rossi, A. (eds.), Riabitare l'Italia: Le aree interne tra abbandoni e riconquiste (pp. 207-231). Donzelli.

D’Alessandro, J. (2020, April 23). Coronavirus, l'illusione della grande fuga da Milano. Ecco i veri numeri degli spostamenti verso sud. la Repubblica. https:/www.repubblica.it/tecnologia/2020/04/23/news/coronavirus_1_illusione_della_grande_fuga_da_milano_e_i_veri_numeri_degli_spostamenti_verso_sud-254722355/

dell'Agnese, E. (2018). Bon voyage: Per una geografia critica del turismo. UTET Università, Torino.

Fieger, P., Prayag, G., Hall, C. M., \& North, C. (2020). The tourism value of international freedom campers to New Zealand. Tourism Recreation Research, 45(2), 265-270. https://doi.org/10.1080/0 2508281.2019.1660042

Financial Times (2020, 25 April). 'Second Home Wars'. Financial Times. 
Finnish Government (2020, March 25). Movement restrictions to Uusimaa - the Government decided on further measures to prevent the spread of the coronavirus epidemic. Press release. https://valtioneuvosto.fi/-/10616/uudellemaalle-liikkumisrajoituksia-hallitus-paatti-uusista-lisatoimista-koronaepidemian-leviamisen-estamiseksi?languageId=en_US

Gallent, N. (2019). Whose housing crisis? Policy Press.

Gallent, N. (2020). Covid-19 and the flight to second homes. Town and Country Planning, 89, 141144.

Grigoryev, L. M. (2020). Global social drama of pandemic and recession. Population and Economics, 4(2), 18-25. https://doi.org/10.3897/popecon.4.e53325

Hall, C. M., \& Müller, D. K. (2018). Caravanning and mobile second homes. In C. M. Hall \& D. Müller (Eds.), The Routledge handbook of second home tourism and mobilities (pp. 291-197). Routledge.

Hall, C. M., Scott, D. \& Gössling, S. (2020). Pandemics, transformations and tourism: Be careful what you wish for. Tourism Geographies, 22(3), 577-598. https://doi.org/10.1080/14616688.2020. 1759131

Hayes, J., \& Loney, G. (2020, March 26). Tourism hotspots divided over visitors as coronavirus casts a shadow over Easter holiday. ABC News. https://www.abc.net.au/news/2020-03-26/ tourists-stay-away-because-of-coronavirus/12090792

Jeskanen, J. (2020). Venäjä ei päästä kansalaisiaan mökeille Suomeen, vaikka Suomi päästäisi. Helsingin Sanomat. https://www.hs.fi/ulkomaat/art-2000006668749.html

Judge, L., \& Rahman, F. (2020). Lockdown living: Housing quality across the generations. Resolution Foundation. https://www.resolutionfoundation.org/app/uploads/2020/07/Lockdown-living. pdf

King, A. (2020, June 23). Can you still rent a cottage this summer during the pandemic? It depends. CBC News. https://www.cbc.ca/news/canada/toronto/renting-a-cottage-during-covid-19-pandemic-1.5597485

Klowak, M. (2020, June 22). Resorts, cottages in Manitoba inundated with bookings from within province and beyond. CBC News. https://www.cbc.ca/news/canada/manitoba/clear-lakewhiteshell-reg-kehler-greg-ftoma-brereton-lake-covid-1.5619607

Kuchler, T., Russel, D. \& Stroebel, J. (2020). The geographic spread of COVID-19 correlates with the structure of social networks as measured by Facebook. NBER Working Paper, No. 26990. http://www.nber.org/papers/w26990

Kurmelovs, R. (2020, June 27). 'Shell shock': Kangaroo Island struggles to recover amid bushfire grief and Covid-19. The Guardian. https://www.theguardian.com/australia-news/2020/jun/28/ shell-shock-kangaroo-island-struggles-to-recover-amid-bushfire-grief-and-covid-19

Lanzani, A., \& Zanfi, F. (2017). Fare Urbanistica dentro il patrimonio residenziale. In E. Fontanari \& G. Piperata (Eds.), Agenda re-cycle: Proposte per reinventare la città (pp. 195-227). Il Mulino. 
Larizza, A. (2020, March 17). «Tornate a casa, ci infettate!»: Turisti e non residenti nel mirino in tutta italia. Economia. https:/www.ilsole24ore.com/art/tornate-casa-ci-infettate-turisti-e-non-residenti-mirino-tutta-italia-ADj7OyD

Länsi-Savo (2020, March 30). Mielipide: Vapaa-ajanasukkaat ovat osa yhteisöämme. Länsi-Savo. https://lansi-savo.fi/mielipide/lukijalta/1b59b5f5-c582-4c36-8049-962302bfd760

Marchetti, S. (2020, June 10). Cinquefrondi: The ‘Covid-free' Italian town selling \$1 houses. CNN. https://edition.cnn.com/travel/article/one-euro-homes-cinquefrondi-covid-19/index.html

Missick, A. (2020, June 15). Here's how funding is being used to revive BC's tourism sector. Daily Hive. https://dailyhive.com/vancouver/bc-tourism-funding

Mochan, K. (2020, March 27). City slickers fleeing homes to sit out coronavirus in the country urged to stay away. ABC News. https://www.abc.net.au/news/2020-03-27/coronavirus-city-slickers-flee-to-country-western-australia/12094808

Monbiot, G. (1999, October 2). Cannibal Feast. The Guardian. https://www.monbiot. com/1999/10/02/cannibal-feast/

MTV (2020, March 20). Suomi on jähmettynyt ja paennut koronaa mökeille - MTV Uutisten saama harvinainen puhelindata paljastaa ihmisvirtojen liikkeet. MTV. https://www.mtvuutiset. fi/artikkeli/suomi-on-jahmettynyt-ja-paennut-koronaa-mokeille-mtv-uutisten-saama-harvinainen-puhelindata-paljastaa-ihmisvirtojen-liikkeet/7767716\#gs.dzgm74

Nikolaeva, U. G., \& Rusanov, A. V. (2020). Self-isolation at the dacha: Can't? Can? Have to? Population and Economics, 4(2), 182-198. https://doi.org/10.3897/popecon.4.e54577

Parhiala, K., Pitkänen, K., Strandell, A., Rehunen, A., \& Suomela, A. (2020). Miten huomioida monipaikkainen elämä terveyspalvelujen järjestämisessä? (Päätösten tueksi 1/2020.) Terveyden ja hyvinvoinnin laitos THL. http://www.julkari.fi/handle/10024/139058

Parhiala, K., Suomela, T., Rehunen, A., Pitkänen, K. \& Strandell, A. (2019). Näkyykö monipaikkaisuus kiireellisessä hoidossa? Alueelliset kausivaihtelut sairaaloiden päivystyksen käytössä 2017. (Tutkimuksesta tiiviisti 21. Toukokuu 2019.) Terveyden ja hyvinvoinnin laitos THL. http://www.julkari.fi/handle/10024/138297

Payne, P. R., Kaye-Blake, W. H., Stirrat, K. A., Ellison, R. A., Smith, M. J., \& Brown, M. (2019). Identifying resilience dimensions and thresholds: Evidence from four rural communities in New Zealand. Resilience, 7(2), 149-171. https://doi.org/10.1080/21693293.2018.1545339

Perri, A. (2016). Residential roots tourism in Italy. In Z. Roca (Ed.), Second home tourism in Europe: Lifestyle issues and policy responses (pp. 53-68). Routledge.

Radio New Zealand (2020, March 28). New Zealand lockdown: Great Barrier-Aotea residents irritated by boaties on shores. RNZ News. https://www.rnz.co.nz/news/national/412812/new-zealand-lockdown-great-barrier-aotea-residents-irritated-by-boaties-on-shores

Rajavartiolaitos (2020a). Usein kysyttyä koronaviruksen vaikutuksista rajanylitysliikenteeseen. https://www.raja.fi/ajankohtaista/ukk_koronavirus 
Kati Pitkänen, Olga Hannonen, Stefania Toso, Nick Gallent, Iqbal Hamiduddin,

Greg Halseth, C. Michael Hall, Dieter K. Müller, Andrey Treivish, Tatiana Nefedova

Rajavartiolaitos (2020b). Руководство пограничной охраны Финляндии о пересечению границы в соответствии с решением Государственного Совета от 12.06.2020. https:// www.raja.fi/ru/infomatciia/pressrelizi/1/0/12_6_2020_80050?fbclid=IwAR3_eEPbuzigJma9XugrynfAIkovESXSGLpDG-7UyzPTVI4R7E03wW9OjSA

Rantala, K. (2020). Etätyömatkailusta on tullut todellisuutta - vaihtelua kotitoimistolle haetaan rakkauden tai mieluisan vapaa-ajan vuoksi. YLE uutiset. https://yle.fi/uutiset/3-11615885?fbclid=IwAR2WKWPZHAWyXG22VlgaHlzLlOj8FFg6S_For_ci_QyuJm_EdY9ADoqCUTY\&utm_ source $=$ twitter-share\&utm_medium $=$ social

Romita, T. (2010). Il turismo residenziale: Nuovi stili di vita e di residenzialità, governance del territorio e sviluppo sostenibile del turismo in Europa. Franco Angeli.

Ross, H. (2020, May 20). Post-COVID-19 wave of regional migration predicted as people seek simpler life, get back to basics. $A B C$ News. https:/www.abc. net.au/news/2020-05-10/post-covid-19-pandemic-simpler-life-migration/12229082

Savon Sanomat (2020, July 7). Korona todella toi vilkkaan mökkeilykesän: Suurissa kesäkunnissa jopa 75 prosenttia enemmän mökkikauppoja kesäkuussa, kaupungeissa viime vuotta selvästi hiljaisempaa. Savon Sanomat. https:/www.savonsanomat.fi/talous/Korona-todella-toi-vilkkaan-m\%C3\%B6kkeilykes\%C3\%A4n-Suurissa-kes\%C3\%A4kunnissa-jopa-75-prosenttia-enemm\%C3\%A4n-m\%C3\%B6kkikauppoja-kes\%C3\%A4kuussa-kaupungeissa-viime-vuotta-selv\%C3\%A4sti-hiljaisempaa/1578347

Scheinin, M., \& Rautiainen, P. (2020). Koronakriisin uusissa toimissa valmiuslain nojalla ollaan nyt poikkeamassa ihmisoikeussopimuksista - valtioneuvosto leikkii jumalaa. (Perustuslakiblogi 26.3.2020). Valtiosääntöoikeudellinen seura. https://perustuslakiblogi.wordpress. $\mathrm{com} / 2020 / 03 / 26 /$ martin-scheinin-pauli-rautiainen-koronakriisin-uusissa-toimissa-valmiuslain-nojalla-ollaan-nyt-poikkeamassa-ihmisoikeussopimuksista-valtioneuvosto-leikkii-jumalaa/

Seraphin, H., \& Dosquet, F. (2020). Mountain tourism and second home tourism as post COVID-19 lockdown placebo? Worldwide Hospitality and Tourism Themes. https://doi.org/10.1108/ WHATT-05-2020-0027

Smålänningen (2020, June 08). Risk för avloppsläckage: Mer tid i stugorna en coornasommar leder till ökat avloppsläckage. Smålänningen, p. 8.

Statistics Finland (2020). Suomalaisten matkailu keskittyi kotimaahan kesällä 2020. https:// www.stat.fi/til/smat/2020/14/smat_2020_14_2020-11-05_tie_001_fi.html

The Local (2020, May 8). Could Italy's abandoned villages be revived after the coronavirus outbreak? The Local. https://www.thelocal.it/20200508/could-italys-abandoned-villages-be-revived-after-the-coronavirus-outbreak

UNCEM (2020, March 13). No al turismo verso le valli Alpine appenniniche... https://uncem.it/ no-al-turismo-verso-le-valli-alpine-e-appenniniche-uncem-giusta-la-preoccupazione-deisindaci-montagne-accoglienti-ma-non-ora-stare-a-casa-fa-bene-anche-alla-montagna/

Uppsala Nya Tidning (2020, April 24). TT-enkät: Flera kommuner stoppar sommarhemtjänst. Uppsala Nya Tidning, p. 19. 
Volo, S. (2018). Second home tourism in Sicily: Development, current trend and future outlook. In C. M. Hall \& D. K. Müller (eds.), The Routledge handbook of second home tourism and mobilities (pp. 191-200). Routledge.

Yle (2020a, March 25). A-studio: Hallituksen tiedotustilaisuus. Yle. https://areena.yle.fi/150484680

Yle (2020b, May 17). Mökki on nyt kapakka, pakopaikka ja turvasatama - vuokramökkien kysyntä nousi pilviin ja nuoretkin haluavat mökeille. Yle. https://yle.fi/uutiset/3-11355569

Yle (2020c, November 13) Rantamökkejä myyty ennätysmäärä 30 vuoteen - kauppojen määrä kasvaa 40 prosenttia viime vuodesta. Yle. https://yle.fi/uutiset/3-11645238

Zogal, V., Domenech, A., \& Emekli, G. (2020). Stay at (which) home: Second homes during and after the COVID-19 pandemic. Journal of Tourism Futures. https://doi.org/10.1108/JTF-062020-0090 